ISSN: 2224-0616

Int. J. Agril. Res. Innov. \& Tech. 1(1\&2): 55-59, December, 2011

Available at http:/ / www.jjarit.webs.com

\title{
QUANTITATIVE ANALYSIS OF a-MANGOSTIN IN MANGOSTEEN FRUIT RIND EXTRACT
}

\section{Azharul Islam ${ }^{*}$ and Shahanara Begum²}

Received 1 October 2011, Revised 23 November 2011, Accepted 25 December 2011, Published online 31 December 2011

The paper has been deleted due to plagiriasm

The original paper is published in Thai J ournal of Agricultural Science 2009, 42 (1): 7-12 (www.thaiagj.org) 